
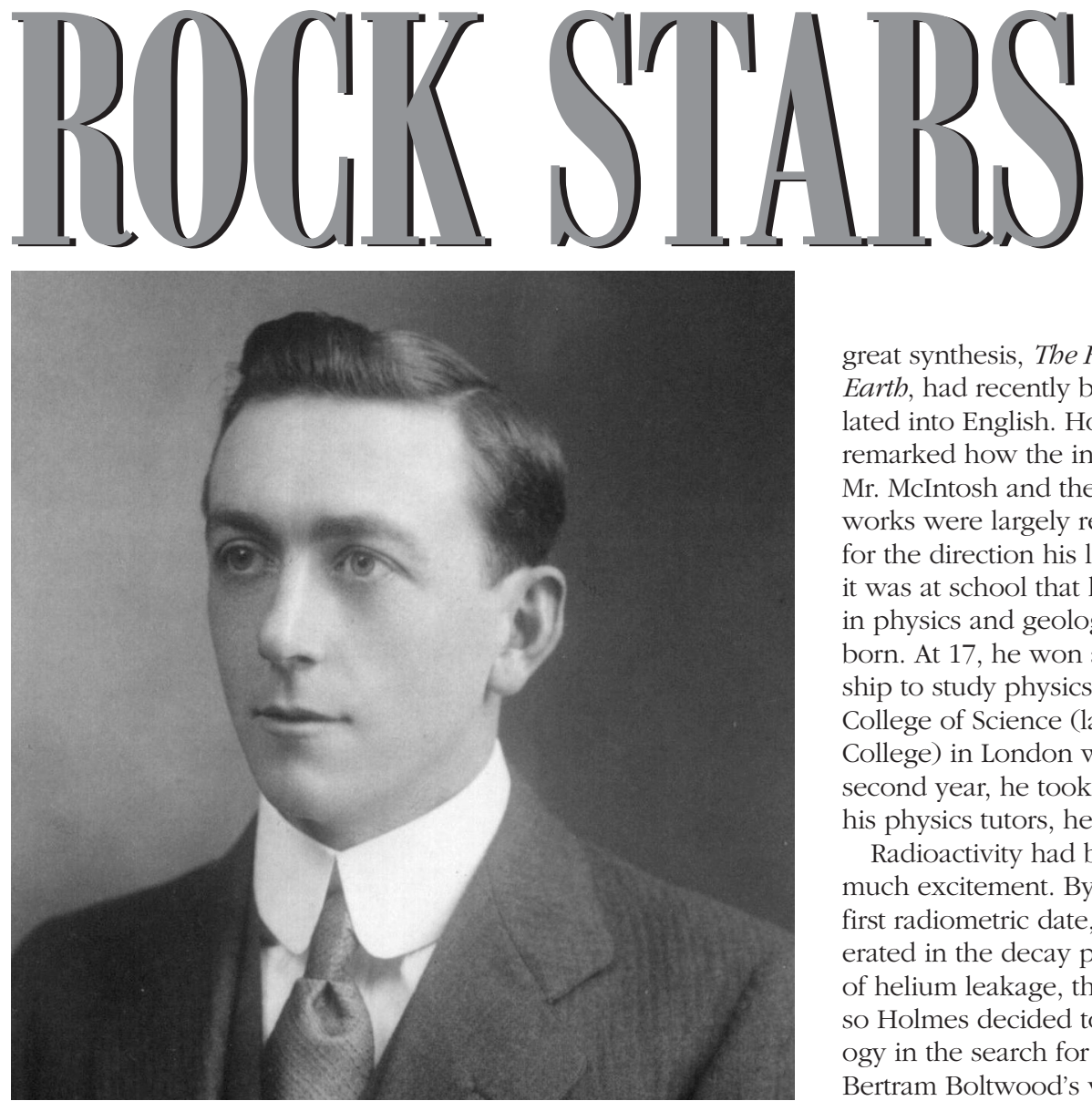

Arthur Holmes as a young man in his early 20s. This photo was probably taken in 1912 when Holmes joined the Geological Society of London.

\section{Arthur Holmes: An Ingenious Geoscientist}

\author{
Cherry L. E. Lewis, University of Bristol, England
}

From an early age, Arthur Holmes (1890-1965) recalled seeing the date of creation- 4004 B.C.-written in the family bible. "I was puzzled by the odd " 4 ," he wrote. "Why not a nice round 4000 years? And why such a very recent date? And how could anyone know?" The latter question set him thinking, for at the turn of the twentieth century, there was no numerical geological time scale and the "age of the Earth" controversy was at its peak: The physicist Lord Kelvin had calculated the age to be around 20 million years; the majority of geologists demanded at least 100 million years, whilst religious dogma required only 6000 years.

\section{A Bright Boy}

Born in Gateshead, the industrial heartland of northeast England, Holmes came from a modest, staunchly Methodist background. At age 15, he gained first-class honors in the School Certificate examinations. In the sixth form, he encountered $\mathrm{Mr}$. McIntosh, who introduced his pupils to the Popular Lectures and Addresses of Lord Kelvin. He also familiarized them with the work of the Swiss geologist Edward Suess, whose first volume of his
}

great synthesis, The Face of the Earth, had recently been translated into English. Holmes later remarked how the inspirational Mr. McIntosh and these two works were largely responsible for the direction his life took, for it was at school that his interests in physics and geology were born. At 17, he won a scholarship to study physics at the Royal College of Science (later Imperial College) in London where, in his second year, he took a course in geology. Against the advice of his physics tutors, he decided to become a geologist.

Radioactivity had been discovered in 1896 and was causing much excitement. By 1904, Ernest Rutherford had determined the first radiometric date, utilizing the discovery that helium was generated in the decay process. Unfortunately, owing to the problem of helium leakage, these early dates were only minimum values, so Holmes decided to combine his interest in physics and geology in the search for an alternative technique. Building on Bertram Boltwood's work, which indicated that lead might be the final decay product of uranium, Holmes performed the very first uranium-lead analysis specifically determined for age-dating purposes. It yielded $370 \mathrm{Ma}$ for a Devonian rock. Aged only 21, he had embarked on his lifetime's quest "to graduate the geological column with an ever-increasingly accurate time scale." In April 1911, the paper was read to members of the Royal Society while Holmes was in Mozambique.

\section{Mozambique}

Living in London on his scholarship of only $£ 60$ (\$100) a year, Holmes continually struggled to make ends meet, so at 21, he took a job prospecting for minerals in Mozambique. After six months, nothing of value was found, and Holmes became so ill with malaria that a notice of his death was telegraphed home. Fortunately, he recovered and immediately caught the boat home where he began writing to geologists such as du Toit and Sederholm, requesting material for dating purposes: "My two chief objects are the formation of a geological time scale and also the correlation of the various members of the Pre-Cambrian rocks in different parts of the world." "Geologising" in Mozambique initiated his lifelong interests.

As a demonstrator at Imperial College, Holmes advanced the infant science of geochronology almost single-handedly. But after isotopes were discovered in 1913, the difficulties of chemically determining the several isotopes of lead meant that progress was slow. Much of this early work was done in collaboration with his best friend from school, Bob Lawson, with whom Holmes shared a passion for physics and music. For almost 30 years, the two friends collaborated on many projects. "I want to discuss it with you....and ask your help in the maths involved," was a typical appeal from Holmes, but Lawson rarely gained the credit he deserved. 


\section{The Age of the Earth}

Following publication of Holmes' famous book The Age of the Earth in 1913 (Harper \& Brothers) in which he estimated the Earth's age to be $1600 \mathrm{Ma}$, Holmes, still only 23, became recognized as the world's authority on the subject. Despite this, opposition from established geologists entrenched in a belief that the Earth was $100 \mathrm{Ma}$ was formidable. Holmes recalled one such occasion during a talk being given at the Geological Society of London in 1915:

I was being violently attacked by the reader of a paper who insisted that the Age of the Earth must be less than 100 million years old. In the discussion that followed I had occasion to refer to the isotopes of lead, then newly discovered. But isotopes did not seem to have been heard of in that audience. The reader of the paper insisted that all atoms of lead must have the same atomic weight, and I found myself in an exasperated minority of one.

\section{Burma}

Holmes remained a demonstrator at Imperial College throughout World War I, but by 1920, with a wife and young son to support, he could no longer afford the luxury of research. He took a job as chief geologist to an oil company in Burma, but again the venture proved unsuccessful and the underfunded company failed to pay its employees. Two years later, Holmes returned to England, bankrupt and devastated by the death of his young son from dysentery. Unable to get a job, he opened a shop selling fareastern knick-knacks, but he never lost sight of his dream.

Eventually, in 1924, following the birth of another son, he was offered the headship of the new geology department being opened at Durham University. His was a department of one.

\section{Continental Drift}

On returning from Burma in 1922, Holmes found that the age of the Earth controversy had largely been settled and even the most conservative geologist accepted the long time scale demonstrated by his dating work. But that debate had been replaced by another: continental drift. While many Europeans considered that the geological evidence strongly supported the theory, the majority were still unable to accept it due to a lack of understanding about how continents moved around the globe. Holmes, however, was one of a small group convinced from the start of the theory's validity. His work on radioactivity, geological time, and petrogenesis had led him to a profound understanding of processes in the Earth's interior. Consequently, he was the first to propose that incredibly slow-moving convection currents in the mantle caused continental breakup, seafloor formation, crustal assimilation, and continental drifting. Despite his theories being ignored, he still taught them to his students for the next 30 years.

Holmes remained at Durham for 19 years and established himself as "one of the few English geologists with ideas on the grand scale," as Reginald Daly described him. In 1932, continuing his search for a simple dating technique, he proposed a "new key to petrogenesis" that described the principle now known as initial ratios. Unfortunately, to illustrate his ideas, he used an assumed radiometric decay scheme $\left({ }^{41} \mathrm{~K} /{ }^{41} \mathrm{Ca}\right)$, which later proved incorrect. Consequently, this fundamental idea that today underpins isotope geochemistry, was also ignored for 30 years.

\section{Principles of Physical Geology}

Following the death of his wife in 1938, Holmes married Doris Reynolds, also a geologist, with whom he found great happiness. During World War II, he wrote his world-famous textbook with its final chapter on continental drift. Principles of Physical Geology
(Thomas Nelson \& Sons) influenced generations of geologists, but by the time it was published in 1944, Holmes had been appointed Regius Professor of Geology at Edinburgh University. It was there, despite his declining health, that he completed some of his most important work on the age of the Earth, the geological time scale, the Precambrian, and the geology of Africa-those lifelong interests triggered by his trip to Mozambique.

With ideas far ahead of his time, Holmes was a deep thinker and philosopher about the really big geological problems. Many honors were heaped upon him, including the Wollaston and Penrose medals in 1956, and the Vetlesen Prize in 1964, but at no presentation was his work on continental drift ever mentioned. In fact, Holmes was considered something of a maverick for his persistent belief in the theory, and it was as "Father of the Geological Timescale" that he was commended.

Holmes lived just long enough to see the dawn of plate tectonics. In 1963, the theory of seafloor spreading was proposed, validating his theories by then almost forgotten. In 1965, the second edition of his Principles of Physical Geology was published, only months before he died. In it he modestly noted that "mantle currents are no longer regarded as inadmissible." Today, Holmes is acclaimed as one of the most important geoscientists of the twentieth century.

\section{Further Reading}

Lewis, C.L.E., 2001, Arthur Holmes' Vision of a Geological Timescale, in Lewis, C.L.E., and Knell, S., eds., The Age of the Earth: from 4004 B.C. to A.D. 2002: London, Geological Society [London], Special Publications 190, p. 121-138.

Lewis, C.L.E., 2000, The Dating Game, Cambridge University Press.

"Rock Stars" is produced by the GSA History of Geology Division. Editorial Committee: Michele Aldrich, Robert Dott (editor of this profile), Robert Ginsburg, and Gerard Middleton.

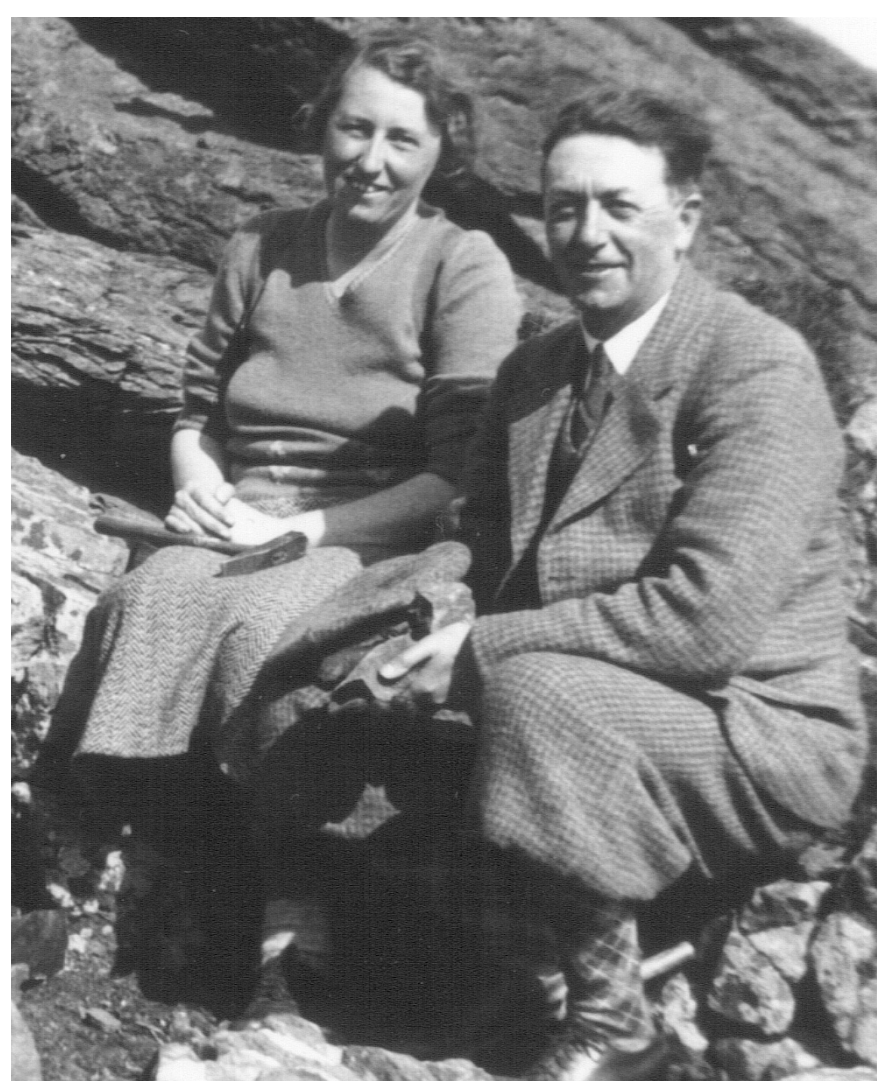

Arthur Holmes and Doris Reynolds, his second wife, in the field, ca. 1940. 